\title{
Sustainable development and its connection to teaching geoethics
}

\author{
${ }^{1}$ Faculty of Sciences of Oporto University, Earth Sciences Institute, Portugal \\ E-mail: csvascon@fc.up.pt; joana.torres@fc.up.pt; sara.moutinho@fc.up.pt \\ ${ }^{2}$ Faculty of Human and Social Sciences of Universidade Fernando Pessoa, Portugal.E-mail: lvasc@ufp.edu.pt;
}

(Received: 02/05/15; Accepted: 12/02/2016)

DOI:10.18814/epiiugs/2016/v39i3/99771

The decade of Education for Sustainable Development (ESD) ended in January 2015 but to some extent this subject remains unknown to many Portuguese citizens. Geoethics has strong links to the three pillars of Sustainable Development (environmental, economic and social) and is evolving rapidly, but the public understanding of its relationship to Sustainable Development is rather poor and the subject is even neglected in Portuguese classrooms.The environmental pillar was undoubtedly the ESD component that has been more widely implemented in Portuguese school classrooms. Nonetheless, the economic and social pillars of ESD require further thought and concern. Indeed, experts in the field found several difficulties in their attempt to integrate ESD into academic programs.

For the purpose of analysing the links between knowledge related to ESD and Geoethics Teaching, an interview-based survey was undertaken with 187 Portuguese citizens. As the results showed a very low knowledge of ESD but a possible linkage with Geoethics Teaching, eight interviews were conducted with basic and secondary science teachers. The purpose of this study is to highlight the possibility of teaching Geoethics throughout the Geoscience Curriculum. Otherwise, the valuable contribution that Geoethics has to offer to Sustainable Development may be lost.

\section{Framework}

For some years, Education for Sustainable Development (ESD) overlapped with the conceptual knowledge of Environmental Education. Although the UN designated the 2004-2015 decade as the decade of Education for Sustainable Development, experts in the field found many difficulties in their attempts to integrate this concept into academic programs (Vasconcelos, 2012). This helps to explain why many citizens still have a limited interpretation of Sustainable
Development, referring to it as mere environmental awareness or as actions related to pro-environmental issues.

Nonetheless, the concept of Sustainable Development is much wider. It refers to economic development, social development and environmental protection. It includes both the idea of present and future sustainability. It introduces a sense of balance between essential needs and the limitations imposed by social organization, economic activity and technology. As the Brundtland Commission put it, Sustainable Development is development that meets the needs of the present without compromising the ability of future generations to meet their own needs (World Commission on Environment and Development, 1987). Indeed, Sustainable Development comprises a concern for both long-term physical sustainability of the environment and social equity between generations. Bearing this conceptualization in mind, a literature review helped the researchers to identify several key dimensions of Sustainable Development, following the traditional economic, social and environmental pillars, notwithstanding the recognition of other key features of human development to which the former pillars are intrinsically related. The dimensions and indicators herein presented (Table 1) are merely illustrative. Ultimately, they converge in the emphasis given to poverty reduction, the change of unsustainable patterns of production and consumption and the protection of the natural resource base of growth and development.

Specific reference should be made to the Human Sustainable Development Index created in 2010 , by adding the per capita carbon emissions to the previously existing Human Development Index (composed of life expectancy at birth, Gross National Income and years of schooling) (UNSD). Nonetheless, there is a huge array of indicators and indexes that can inform Sustainable Development under different perspectives. Ultimately, their selection tends to follow the study objectives of the researcher and is often limited by data availability.

Three experts in Sustainable Development validated the list (Table 1) and suggested corrections and improvements. Although the focus of the research was Geoethics rather than Sustainable Development in itself, following this validation process we used the checklist to conduct a content analysis on our sample of 187 interviews with Portuguese citizens.

Geoethics is a path for Sustainable Development (Vasconcelos and Almeida, 2014). Sustainable Development integrates the ethical dimension of Geoethics linked to the concern and the responsibility 
Table 1. Measuring Sustainable Development

\begin{tabular}{|c|c|c|}
\hline Pillar & Dimension & Indicators (v.g.) \\
\hline $\begin{array}{l}\text { Environmental } \\
\text { A sustainable environment must guarantee a stable } \\
\text { resource base, avoiding an overlap of renewable } \\
\text { resource systems and the exploitation of non- } \\
\text { renewable sources of funds only to the extent of } \\
\text { the investments made in the search for resources } \\
\text { and alternative energies. This implies a concern } \\
\text { for maintenance of biodiversity, atmospheric } \\
\text { stability and other ecosystem functions that are } \\
\text { usually not directly classified as economic } \\
\text { resources. }\end{array}$ & $\begin{array}{l}\text { Climate change } \\
\text { Pollution } \\
\text { Ozone layer } \\
\text { Biodiversity } \\
\text { Fishery resources } \\
\text { Forest resources } \\
\text { Land/soil } \\
\text { Water resources }\end{array}$ & $\begin{array}{l}\text { Primary energy supply, Air quality index, Outdoor air } \\
\text { pollution, Indoor air pollution, Carbon dioxide emission } \\
\text { per capita, Expenditure on air pollution reduction } \\
\text { Reduction carbon emissions } \\
\text { Depletion of mineral resources } \\
\text { Deforestation rate, Threatened, extinct species } \\
\text { Marine water resources, Catches of marine species } \\
\text { Arable land per capita, Area affected by soil erosion } \\
\text { Use of fertilizers, Use of agricultural pesticides } \\
\text { Land affected by desertification } \\
\text { Access to safe drinking water, Area affected by } \\
\text { salinization, Water use per GDP, Domestic consumption } \\
\text { of water per capita, Waste water treatment, Industry, } \\
\text { agriculture and municipal discharges, } \\
\text { Others }\end{array}$ \\
\hline $\begin{array}{l}\text { Social } \\
\text { A sustainable social system is one that achieves } \\
\text { fair distribution, the provision of basic social } \\
\text { services, including health and education, gender } \\
\text { equality, governance transparency and citizen } \\
\text { participation. }\end{array}$ & $\begin{array}{l}\text { Demography } \\
\text { Poverty } \\
\text { Health } \\
\text { Gender equality } \\
\text { Education } \\
\text { Governance } \\
\text { Participation } \\
\text { Freedom }\end{array}$ & $\begin{array}{l}\text { Population growth rate, Population density, Urban/rural } \\
\text { migration rate, Rate of growth of urban population } \\
\text { Life expectancy at birth, Statutory pension age population } \\
\text { Population living in absolute poverty, Population below } \\
\text { income poverty line, Persons at-risk-of-poverty or social } \\
\text { exclusion, Calorie supply per capita, Child labour } \\
\text { Unimproved sanitation or poor hygiene } \\
\text { Pupil-teacher ratio, Primary and secondary school } \\
\text { enrolment ratio, Literacy rates, Females per } 100 \text { males } \\
\text { in secondary school, School dropout, Expected years of } \\
\text { schooling, Research and development expenditure } \\
\text { Life expectancy at birth, Mortality rates, Maternal } \\
\text { mortality ratio, Health care quality, Adult health, } \\
\text { Adolescent birth rate, HIV prevalence, Child } \\
\text { malnutrition, Gender-related development index, } \\
\text { Gender Inequality Index, } \\
\text { Labour Force Participation rate, Activity and } \\
\text { employment by gender, Political participation, } \\
\text { Human Development Index, Human Sustainable } \\
\text { Development Index, Others }\end{array}$ \\
\hline $\begin{array}{l}\text { Economic } \\
\text { A sustainable economic system must be able to } \\
\text { produce goods and services on a continuous basis, } \\
\text { avoiding sectorial imbalances that may cause } \\
\text { irreparable damage to the natural resource base } \\
\text { of economic production and guaranteeing adequate } \\
\text { levels of growth and labour with economic and } \\
\text { financial equilibriums. }\end{array}$ & $\begin{array}{l}\text { Growth } \\
\text { Internal market } \\
\text { Equity } \\
\text { International market } \\
\text { Public Finances } \\
\text { Prices } \\
\text { Competitiveness } \\
\text { Job-creation } \\
\text { Natural resource } \\
\text { base of economic } \\
\text { and social } \\
\text { development }\end{array}$ & $\begin{array}{l}\text { Gross Domestic Product, Growth rate of real GDP, } \\
\text { GNI per capita, Gini coefficient, GDP expenditure } \\
\text { components, Balance of payments } \\
\text { Foreign direct investment, Net inflows, External debt } \\
\text { Public Deficit, Public debt, Total public debt service } \\
\text { Inflation, Resources productivity, Relationship between } \\
\text { wages and productivity } \\
\text { Employment to population ratio, Unemployment rate } \\
\text { Employment rate of older workers } \\
\text { Production and consumption patterns, Primary energy } \\
\text { consumption, Annual energy consumption per capita, } \\
\text { Share of renewable energy in final energy consumption, } \\
\text { Governmental expenditure - health and education, } \\
\text { Governmental expenditure - environmental protection, } \\
\text { Others }\end{array}$ \\
\hline
\end{tabular}


of guaranteeing that the needs of the present are met without compromising the sustainability of future generations. Bearing this ethical dimension in mind, Geoethics is particularly concerned with the way humans relate to the geosphere (Matteucci et al., 2014). At the same time, Geoethics focuses on how geologists develop their academic and professional work which impacts in sustainability (Almeida and Vasconcelos, 2014). Accordingly, the website of the International Association for Promoting Geoethics (IAPG) highlights the following dimensions of Geoethics:

- Geoethics provides a reference and guidelines for behaviour in addressing concrete problems of human life by trying to find socio-economic solutions compatible with a respect for the environment and the protection of Nature and land.

- Geoethics reflects the social role played by Geoscientists and their responsibilities highlighting the ethical, cultural and economic repercussions that their behavioral choices may have on society.

- Geoethics encourages a critical analysis of the use and management of geo-resources.

- Geoethics deals with problems related to the risk management and the mitigation of geohazards.

- Geoethics fosters the proper and correct dissemination of the results of scientific studies and other information on risks.

- Geoethics aims to improve the relationships between the scientific community, the mass media and the public.

- Geoethics promotes the development of the geoparks and geotourism, in order to create social awareness about the value of the geological heritage and geodiversity.

- Geoethics highlights the value and usefulness of the geological and geophysical knowledge in daily life by promoting disciplines like geomedicine and forensic geosciences.

- Geoethics aims to organize effective teaching tools to develop awareness, values and responsibility, especially amongst the young people.

Despite its infancy as a scientific and disciplinary field, it took less than two decades to develop this concept, which initially only focused on natural resources. A more elaborate and wider definition, from 2013, can be found in site of the above mentioned association:

- Geoethics consists of the research and reflection on those values upon which to base appropriate behaviours and practices where human activities intersect the Geosphere.

- Geoethics deals with the ethical, social and cultural implications of geological research and practice, providing a point of intersection for Geosciences, Sociology and Philosophy.

- Geoethics represents an opportunity for Geoscientists to become more conscious of their social role and responsibilities in conducting their activity.

- Geoethics is a tool to influence the awareness of society regarding problems related to geo-resources and geoenvironment.

Geoethics is a new field of Geosciences and the diagnosis and dissemination of its knowledge is pressing for future geologists and geology teachers (Almeida and Vasconcelos, 2014), as well as for students and citizens. However, the issue of Geoethics does not easily find acceptance in most respected scientific journals of the scientific community (Peppoloni and Di Capua, 2015).

\section{Method}

In order to apprehend the knowledge and opinions of Portuguese citizens regarding Sustainable Development and its connection to Geoethics, this research followed two stages - the first one assessed the knowledge of Sustainable Development by Portuguese citizens; the second, analysed the possibility of aligning teaching geoethics with the geoscience curriculum.

In the first stage - assessment of the knowledge of Sustainable Development by Portuguese citizens - 187 structured interviews were conducted by two members of the research team who asked for the collaboration of Portuguese citizens in a public space (the citizen bureau).

Two main questions were asked: (i) What do you understand by Sustainable Development? and (ii) Do you consider that teaching Geoethics in basic and secondary education helps students to develop a better knowledge of Sustainable Development? Why? - Please bear in mind that "Geoethics is a subject that discusses principles which guide scientists on how to deal with the non-living part of the planet".

Interviews were audio-taped and transcribed for a better and more reliable data analysis. Statistical analysis of content was subsequently established with the help of the Q.S.R. NVivo 10 qualitative data analysis package and version 22 of the Statistical Package for the Social Sciences - SPSS. Two members of the research team conducted the content analysis based on the previously designed and validated checklist (Table 1).

The sample was divided into 5 categories, according to the age of the respondents, so as to allow a broader content and descriptive analysis (Table 2).

Table 2. Characterization of the sample of the first stage of the study

\begin{tabular}{lllll}
\hline Classes & Age & $\begin{array}{l}\text { Female } \\
\mathrm{f}(\%)\end{array}$ & $\begin{array}{l}\text { Male } \\
\mathrm{f}(\%)\end{array}$ & $\begin{array}{l}\text { Total } \\
\mathrm{f}(\%)\end{array}$ \\
\hline Class 1 & $1-19$ & $1(1.1)$ & $4(4.0)$ & $5(2.7)$ \\
Class 2 & $20-39$ & $34(39.1)$ & $27(27.0)$ & $61(32.6)$ \\
Class 3 & $40-59$ & $31(35.6)$ & $40(40.0)$ & $71(38.0)$ \\
Class 4 & $60-79$ & $20(23.0)$ & $28(28.0)$ & $48(25.7)$ \\
Class 5 & $80-99$ & $1(1.1)$ & $1(1.0)$ & $2(1.1)$ \\
Total & & $87(46.5)$ & $100(53.5)$ & $187(100)$ \\
\hline
\end{tabular}

The sample consisted of 100 men (53.5\%) and 87 women (46.5\%) with ages ranging from 18 to 84 (average age $=47.23$ ).

The second stage of the study - analysing the possibility of aligning teaching geoethics with the geoscience curriculum - was structured following the interpretation of the 187 interviews. It included 8 further interviews with teachers from the basic and secondary school years: 2 teachers from the primary grade of basic school (age range of children from 6 to 9); 2 teachers from the second grade of basic school (ages from 10 to 11); 2 teachers from the third grade of basic school (ages from 12 to 14) and 2 teachers from secondary school (ages from 15 to 17).

As previously stated, the purpose of this second part of the research

Table 3. Characterization of the sample of the second stage of the study

\begin{tabular}{|c|c|c|c|c|}
\hline Classes & Age & $\begin{array}{l}\text { Female } \\
\mathrm{f}(\%)\end{array}$ & $\begin{array}{l}\text { Male } \\
\mathrm{f}(\%)\end{array}$ & $\begin{array}{l}\text { Total } \\
\mathrm{f}(\%)\end{array}$ \\
\hline Class 2 & $20-39$ & $3(37,5)$ & $2(25)$ & $5(62.5)$ \\
\hline Class 3 & $40-59$ & $3(37,5)$ & $0(0)$ & $3(37.5)$ \\
\hline Total & & $6(75)$ & $2(25)$ & $8(100)$ \\
\hline
\end{tabular}


was to examine the possibility of aligning teaching geoethics with the geoscience curriculum. Accordingly, the participants were intentionally selected, because of their knowledge on ESD and Geoethics. The characterization of this second sample is presented in Table 3.

The sample consisted of 2 men (25\%) and 6 women (75.5\%) with ages ranging from 27 to 56 (average age $=37.6$ ). With the exception of the elementary teachers, all the interviewees were graduates in Natural Sciences, which includes Biology and Geology subjects.

\section{Results}

The results of the research are presented in the following two sections, each related to the corresponding stage of the study.

\section{First Stage: What is this thing called Sustainable Development?}

\section{Descriptive Analysis}

Relating to the first question - "What do you mean by Sustainable Development?" - the majority of respondents (62.6\%) did not provide a satisfactory answer. In fact, $41.2 \%$ of respondents answered "I do not know" and $21.4 \%$ gave a nonsensical and confusing answer. Only $37.4 \%$ offered a meaningful answer regarding the definition of Sustainable Development and only 6 individuals (3.2\%) referred to the three pillars of Sustainable Development: economic, social and environmental (Table 4).

The environmental pillar was the most referred to (19.3\%). Eight respondents pointed out the social pillar (4.3\%) and 12 respondents signalled the economic pillar (6.4\%). Five respondents $(2.7 \%)$ mentioned both the environmental and economic pillars, 2 respondents $(1.1 \%)$ referred to both the social and economic pillars and only one respondent $(0.5 \%)$ mentioned the social and environmental pillars. Some of the answers that were given to the first question are presented in Table 5 .

Regarding the second question, 93 respondents (49.7\%) thought that teaching Geoethics in secondary education helps students to develop a better understanding of Sustainable Development. The justifications that were given were mainly associated with environmental $(\mathrm{f}=37,19.8 \%)$ and social $(\mathrm{f}=32,17.1 \%)$ concerns, as presented in Table 6 .

Only 6 respondents $(3.2 \%)$ considered that teaching Geoethics in secondary education did not help students to develop a better perception of Sustainable Development. Respondent 82 said:

"No, the better or worst understanding of what is good or bad for the planet is not related with the quantity of information (...) I do not think that we need to teach Geoethics to understand what happens with our resources".

Ten respondents (5.3\%) did not have an opinion considering this question and 78 respondents $(41.7 \%)$ did not answer it (note that the majority of them had not known how to answer to the previous question) (Table 7).

\section{Statistical Analysis}

A correlational analysis was performed between the variables of the study. Firstly, the existence of a correlation between the ages of the respondents and the answers given to questions 1 and 2 was tested; then the existence of a correlation between gender and the answers given to questions 1 and 2 was tested. In both cases, the results showed that there was no significant correlation between them. According to these results, age and gender do not influence the answers given to questions 1 and 2. When comparing the answers given to questions 1 and 2, the latter on the importance of teaching Geoethics, no correlation was found either (Table 8).

When comparing the answers given to question 1 and the reasons justifying the importance of Geoethics for a better perception of Sustainable Development, no significant correlation was found $(\mathrm{r}=$ $0.19, \mathrm{p}=0.068)$. This result may be related to the fact that the Portuguese give more relevance to the social and environmental pillars when it comes to the understanding of Geoethics. In fact, only one respondent mentioned economic reasons when justifying the importance of teaching Geoethics (Table 9).

\section{Second Stage: Teaching Geoethics across the Geoscience Curriculum}

\section{Descriptive Analysis}

Relating to the first question - "What do you mean by Sustainable Development?"- teachers from different grades showed a relative knowledge of sustainable development, though very much linked to worries related to resource management and the environmental pillar and less concerned with the social and economic context and other implicit interrelations (Table 10).

Relating to the second question - Do you consider that teaching

Table 4. Answers given to question 1 according to gender (Female - left; Male - right)

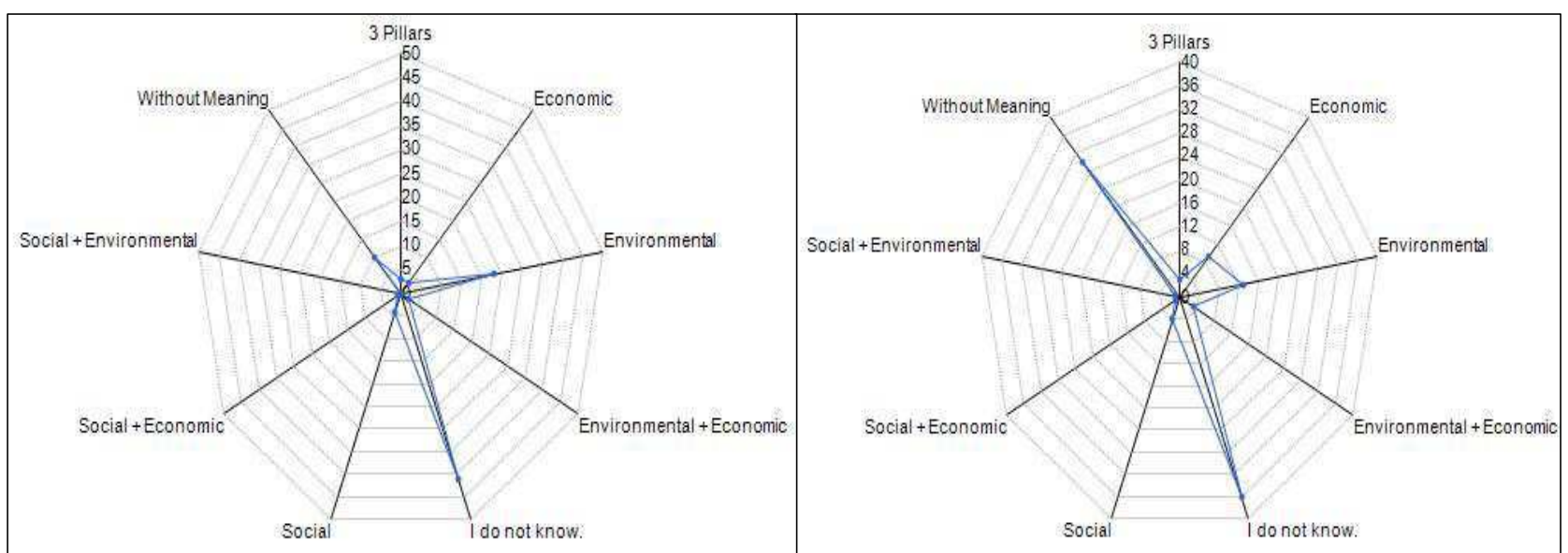


Table 5. Examples of the answers given to question 1: What do you mean by Sustainable Development?

\begin{tabular}{|c|c|c|}
\hline $\begin{array}{l}\text { Category of } \\
\text { Answer }\end{array}$ & $\mathrm{f}(\%)$ & Examples \\
\hline Environmental & $36(19.3)$ & $\begin{array}{l}\text { "It is a development in which there is an ecological concern, and which is very } \\
\text { careful with the industrial development so as to avoid pollution (...), to create } \\
\text { green spaces and sustainable homes." (R138) }\end{array}$ \\
\hline Social & $8(4.3)$ & $\begin{array}{l}\text { "It is very difficult to answer this question. It would be good if everyone held } \\
\text { hands and joined in an idea of peace, peace for all, to have bread for everyone, } \\
\text { that's what was needed." (R185) }\end{array}$ \\
\hline Economic & $12(6.4)$ & "Sustainable Development is not to spend more than what you earn..." (R159) \\
\hline $\begin{array}{l}\text { Environmental + } \\
\text { Economic }\end{array}$ & $5(2.7)$ & $\begin{array}{l}\text { "It is... to use renewable energy sources, everything that is renewable, everything } \\
\text { that does not harm the environment"(R58) }\end{array}$ \\
\hline Environmental + Social & $1(0.5)$ & $\begin{array}{l}\text { "Growth with no risk to the population, with no environmental risks, with respect } \\
\text { for everyone (...)" (R157) }\end{array}$ \\
\hline Social + Economic & $2(1.1)$ & $\begin{array}{l}\text { "It is to produce to consume, to create synergies between companies, (...) to be } \\
\text { employable and to have works available (...), to have money to spend in } \\
\text { consumption,..."( } \mathrm{R} 178)\end{array}$ \\
\hline 3 Pillars & $6(3.2)$ & $\begin{array}{l}\text { "It is a development that respects environmental conditions, the socio-economic } \\
\text { issues of the people and human rights. I think that is a development with quality } \\
\text { of life (...) a development that does not harm the quality of life and nature, and } \\
\text { recognizes that we, as human beings, are members of nature." (R125) }\end{array}$ \\
\hline Without Meaning & $40(21.4)$ & - \\
\hline
\end{tabular}

Table 6. Justifications regarding the relevance of teaching Geoethics

\begin{tabular}{|l|c|l|}
\hline Justification & $\mathrm{F}(\%)$ & Examples \\
\hline Environmental & $37(19.8)$ & $\begin{array}{l}\text { "Yes, I think so, because we can get more sense of things and we can, for example, } \\
\text { help the planet through recycling"(R37) }\end{array}$ \\
\hline Social & $32(17.1)$ & $\begin{array}{l}\text { "Yes, I think that everything that could benefit humanity must be put into practice } \\
\text { (implemented). So, we must teach good values... There is one thing very important } \\
\text { in life: to be able to distinguish what is good from what is bad (...) By making this } \\
\text { distinction, we can choose." (R24) }\end{array}$ \\
\hline Economic & $1(0.5)$ & $\begin{array}{l}\text { "Yes, because there are some countries, that are not considered to be developed, } \\
\text { that are much more sustainable than us; they do not waste resources, the gas and } \\
\text { the electricity as we do (...)" (R153) }\end{array}$ \\
\hline Environmental + Social & $10(5.3)$ & $\begin{array}{l}\text { "Yes, I think so... most of all, so as to convey a mindful awareness regarding } \\
\text { environmental protection, which is important... the ability to convey something to } \\
\text { future generations." (R163) }\end{array}$ \\
\hline 3 Pillars & $1(0.5)$ & $\begin{array}{l}\text { "Yes (...). I think it is a question of values. In the past all people valued what came } \\
\text { from the earth, because it sustained them. Nowadays, people only exploit the earth, } \\
\text { some awareness is lacking and everything is easier (...) Nobody cares, nobody sees } \\
\text { Throughout the years, people began thinking only in numbers, numbers in the short } \\
\text { term and they no longer worry with the long term repercussions. (...)" (R168) }\end{array}$ \\
\hline Without justification & $12(6.4)$ & \begin{tabular}{l} 
r \\
\hline
\end{tabular} \\
\hline
\end{tabular}

Geoethics in basic and secondary education helps students to develop a better knowledge of Sustainable Development? Why? - Please bear in mind that "Geoethics is a subject that discusses principles which guide scientists on how to deal with the non-living part of the planet" -Table 11 presents some citations of the given answers. In general, all teachers recognized the relevance of a transverse approach to the subject of sustainable development across the different curricular years.

Relating to the third question - Do you consider it important to teach Geoethics in Primary/Secondary schooling years? Why? What can Geoethics teach? -all teachers recognized the importance of teaching Geoethics from an early age and throughout the curricula. Nonetheless, a relevant note was made regarding the best age for students to apprehend the concept of Geoethics and its implications in terms of day-to-day behaviour. Though students at younger ages seem to be more eager and receptive to new concepts, they still lack the knowledge and skills to fully understand the relevance of Geoethics. On the other hand, in later school years, students are already 
Table 7. Answers regarding the importance of Geoethics $(n=187)$

\begin{tabular}{|c|l|c|c|}
\hline Q2 & Justification & Frequency & \% \\
\hline \multirow{3}{*}{ Yes } & Environmental & 37 & 19.8 \\
& Social & 32 & 17.1 \\
& Economic & 1 & 0.5 \\
& Environmental + Social & 10 & 5.3 \\
& 3 Pillars & 1 & 0.5 \\
Without justification & 12 & 6.4 \\
\hline \multirow{2}{*}{ No } & Not practical & 6 & 3.2 \\
\hline \multicolumn{2}{|c|}{ I don't know } & 10 & 5.3 \\
\hline \multicolumn{2}{|c|}{ Without answer } & 78 & 41.7 \\
\hline \multicolumn{2}{|l|}{ Total }
\end{tabular}

Table 8. Frequencies of the answers to questions 1 and $2(n=110)$

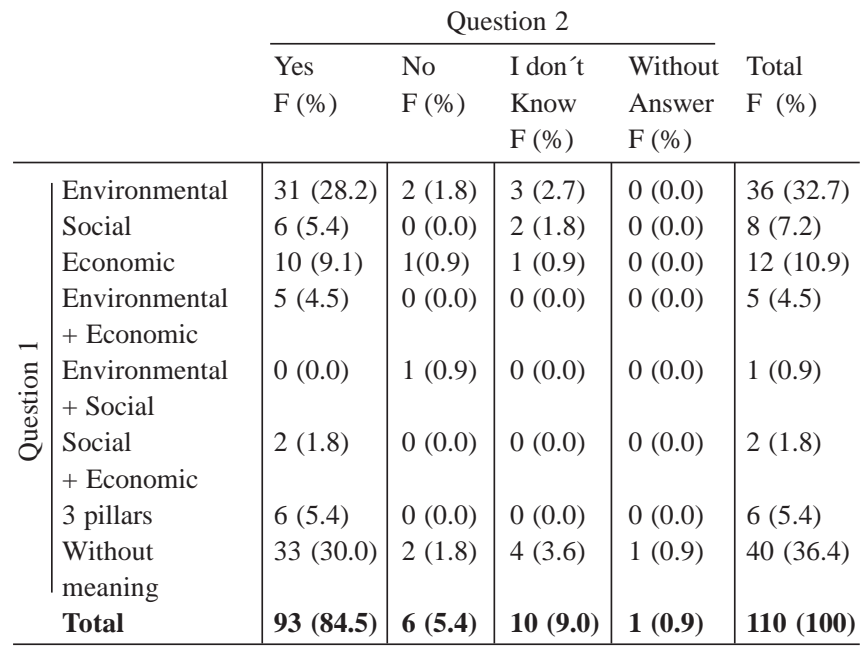

Note that the respondents who did not know how to answer question 1, did not answer question 2 and were excluded from this comparison.

sufficiently knowledgeable and skilful, but they may already have become accustomed to behaviours that disregard Geoethics and which they will not let go of easily. This is a relevant matter that asks for the contribution of Educational Psychology, but it does not diminish the relevance of transversely aligning Geoethics to the different curricula across the different school years. However, it does call for different teaching approaches.

It should also be noted that the teachers' recognition of the relevance of teaching Geoethics was closely linked to the environmental pillar of sustainable development (Table 12). Somehow, just as it happened in the first stage of the study, the social and economic pillars remained in the background.

Relating to the fourth question - According to the curricula goals for teaching natural sciences/geology, in which topics would you include notions of Geoethics? - all teachers referred to topics related to the dynamics of ecosystems and the sustainability of the Earth, again overlooking any social and economic issues.

Only two teachers referred to a relation between Geoethics and individual and community health issues. Furthermore, several Geoethics issues weren't referred at all, indicating that they might not yet be recognized by teachers and thus are not addressed in the classroom. For example, there is no straight recognition of the following: (i) trying to find socio-economic solutions compatible with the respect for the environment and the protection of Nature and land; (ii) the social role played by Geoscientists and the impact of their behaviour and choices on society; (iii) problems related to risk management and reducing geohazards; (iv) the importance of the development of the geoparks and geo-tourism, in order to create social awareness about the value of the geological heritage and geodiversity; (v) the usefulness of the geological and geophysical knowledge in daily life by promoting disciplines like geomedicine and forensic geosciences; (vi) the correct dissemination of the results of scientific studies and other information; (vii) the need to improve the relationship between the scientific community, the mass media and the public.

\section{Conclusions and Educational Implications}

Content analysis of the interviews with 187 Portuguese citizens led to the conclusion that there is a low level of knowledge on the three pillars of Sustainable Development. Only six participants referred to the social, environmental and economic pillars as relevant for Sustainable Development. This conclusion is worrying since it means that the activities and strategies applied during the decade for Education for Sustainable Development were unable to reach these respondents.

Although the majority of the interviewees agreed with the relevance of teaching Geoethics in basic and secondary education, that relevance was mostly linked to environmental and social issues without any recognition of the fundamental relationship between the

Table 9. Frequencies of answers to question 1 and the reasons that justify the importance of Geoethics for a better perception of Sustainable Development $(n=93)$

\begin{tabular}{|c|c|c|c|c|c|c|c|c|}
\hline & & \multicolumn{6}{|c|}{ Justification 2} & \multirow{3}{*}{ Total } \\
\hline & & \multicolumn{6}{|c|}{$\mathrm{f}(\%)$} & \\
\hline & & Environmental & Social & Economic & $\begin{array}{l}\text { Environmental + } \\
\text { social }\end{array}$ & 3 Pillars & $\begin{array}{l}\text { Without } \\
\text { Justification }\end{array}$ & \\
\hline \multirow{8}{*}{ 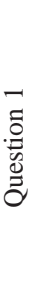 } & Environmental & $16(17.2)$ & $7(7.5)$ & $1(1.1)$ & $5(5.4)$ & 0 & $2(2.1)$ & $31(33.3)$ \\
\hline & Social & $2(2.1)$ & $1(1.1)$ & 0 & $1(1.1)$ & 0 & $2(2.1)$ & $6(6.4)$ \\
\hline & Economic & $5(5.4)$ & $4(4.3)$ & 0 & 0 & 0 & $1(1.1)$ & $10(10.7)$ \\
\hline & Environmental + economic & $2(2.1)$ & $2(2.1)$ & 0 & 0 & $1(1.1)$ & 0 & $5(5.4)$ \\
\hline & Social + economic & $1(1.1)$ & $1(1.1)$ & 0 & 0 & 0 & 0 & $2(2.1)$ \\
\hline & 3 pillars & $3(3.2)$ & $3(3.2)$ & 0 & 0 & 0 & 0 & $6(6.4)$ \\
\hline & Without meaning & $8(8.6)$ & $14(15.0)$ & 0 & $4(4.3)$ & 0 & $7(7.5)$ & $33(35.5)$ \\
\hline & Total & $37(39.8)$ & $32(34.4)$ & $1(1.1)$ & $10(10.7)$ & $1(1.1)$ & $12(12.9)$ & $93(100)$ \\
\hline
\end{tabular}

Note that only those respondents who considered that teaching Geoethics in secondary education helps students to develop a better perception of Sustainable Development were included in this analysis. 
Table 10. What do you mean by Sustainable Development?

\begin{tabular}{|c|c|c|}
\hline Teachers & Code & Citations \\
\hline \multirow[t]{2}{*}{$\begin{array}{l}1^{\text {st }} \text { Grade of } \\
\text { Basic School }\end{array}$} & 1 & $\begin{array}{l}\text {... it is the ability of managing those resources that nature provides in a way that they last as long as } \\
\text { possible. }\end{array}$ \\
\hline & 2 & $\begin{array}{l}\text {... I think it is the confrontation between what is produced and what is spent, it is the confrontation } \\
\text { between the two ... There is a population ... There has to be production of food for this population, } \\
\text { there must be a sustainable development, where no major losses or serious shortages occur. }\end{array}$ \\
\hline \multirow{2}{*}{$\begin{array}{l}2^{\text {nd }} \text { Grade of } \\
\text { Basic School }\end{array}$} & 3 & It is to have environmental or technological development, but always thinking of the future generations. \\
\hline & 4 & Hum ... it must be a set of actions that allow saving the available resources such as water, for example! \\
\hline \multirow[t]{2}{*}{$\begin{array}{l}3^{\text {rd }} \text { Grade of } \\
\text { Basic School }\end{array}$} & 5 & $\begin{array}{l}\text { It relates to the use of resources in such a way that ensures that future generations benefit from the same } \\
\text { quality of life that we have today. }\end{array}$ \\
\hline & 6 & $\begin{array}{l}\text { It is a part of science in which we seek to arise students' awareness and to develop their skills in order } \\
\text { for them to interact with ecosystems responsibly, so that these can be sustained and continue to exist } \\
\text { on this/our planet. }\end{array}$ \\
\hline \multirow[t]{2}{*}{$\begin{array}{l}\text { Secondary } \\
\text { School }\end{array}$} & 7 & $\begin{array}{l}\text { It is to manage the exploitation of resources in such a way that Men can use and take advantage of them } \\
\text { as they need them, but managing them so that future generations can also benefit from those resources. } \\
\text { That is, guaranteeing that they not compromise the satisfaction of the needs of future generations. }\end{array}$ \\
\hline & 8 & $\begin{array}{l}\text { That will be a scientific, technological or social development that does not jeopardize future generations. } \\
\text { For example, mineral resources, water resources, biological resources, including forests ... the trees. }\end{array}$ \\
\hline
\end{tabular}

Table 11. Do you consider that teaching Geoethics in basic and secondary education helps students to develop a better knowledge of Sustainable Development? Why?

\begin{tabular}{|c|c|c|}
\hline Teachers & Code & Examples \\
\hline \multirow{2}{*}{$\begin{array}{l}1^{\text {st }} \text { Grade of } \\
\text { Basic School }\end{array}$} & 1 & If a small approach is considered, yes. \\
\hline & 2 & $\begin{array}{l}\text { I believe so. In the 1st cycle I believe kids have a capability for assimilating contents that is much higher } \\
\text { than in later stages. }\end{array}$ \\
\hline \multirow[t]{2}{*}{$\begin{array}{l}2^{\text {nd }} \text { Grade of } \\
\text { Basic School }\end{array}$} & 3 & $\begin{array}{l}\text { I believe so, let's try soon enough since they are still so little (...) maybe not by directly referring to the } \\
\text { term Geoethics, but rather by addressing the situation and explaining to them that they have a very } \\
\text { important role, that relates not only to them but also for those who come next. }\end{array}$ \\
\hline & 4 & $\begin{array}{l}\text { I believe so, I believe so. I think it is important to arise the children's awareness for sustainable } \\
\text { development from an early age... and then, they themselves end up conveying that knowledge to adults - } \\
\text { parents and teachers around them. }\end{array}$ \\
\hline \multirow[t]{2}{*}{$\begin{array}{l}3^{\text {rd }} \text { Grade of } \\
\text { Basic School }\end{array}$} & 5 & $\begin{array}{l}\text { Undoubtedly. Especially since, to some extent, young people are much more concerned with the living } \\
\text { parts, and seem rather disconnected from the lithosphere and the geosphere. It is as if it is untouchable, } \\
\text { is it always there, it is infinite. I believe it is important for them to realize that without lithosphere there } \\
\text { is no biosphere, and as such, if we do not preserve the lithosphere... it is the basis of all other subsystems. }\end{array}$ \\
\hline & 6 & $\begin{array}{l}\text { There is no doubt. Planet earth is the base of our sustainability. If we do not know how to preserve it, or } \\
\text { how to act, we will make mistakes that clearly we will pay in the future. To teach one student to have the } \\
\text { right attitude (...) to make them realize that their actions are not immediate nor isolated. }\end{array}$ \\
\hline \multirow[t]{2}{*}{$\begin{array}{l}\text { Secondary } \\
\text { School }\end{array}$} & 7 & $\begin{array}{l}\text { Yes ... maybe not by using that term ... from what I understood from the definition of Geoethics (I had } \\
\text { never heard of the term) it seems to me that it is parallel to sustainable development... to know how } \\
\text { can we manage resources so as to ensure that they are not depleted in the future... }\end{array}$ \\
\hline & 8 & $\begin{array}{l}\text { Yes, in the sense that teaching Geoethics (comparing it to bioethics), helps to introduce some values } \\
\text { related to the preservation of what is not alive, including soil, rocks, and all kind of geological heritage. }\end{array}$ \\
\hline
\end{tabular}

pillars that relate to poverty reduction, the change of unsustainable patterns of production and consumption and the protection of the natural resource base of growth and development.

Only a few respondents knew the meaning of the new area of Geoethics, recognized its connections with the three pillars of Sustainable Developmentand thereby acknowledged the relevance of its teaching. Again, this is rather disquieting. Although the concern for Sustainable Development is becoming increasingly present in dayto-day practices, this process is still excessively slow and insufficient, with significant negative impacts on long-term physical sustainability and social equity between generations.

Teachers consider that teaching Geoethics would help students 
Table 12. Do you consider it important to teach Geoethics in Primary/Secondary school years? Why? What can Geoethics teach?

\begin{tabular}{|c|c|c|}
\hline Teachers & Code & Examples \\
\hline \multirow[t]{2}{*}{$\begin{array}{l}1^{\text {st }} \text { Grade of } \\
\text { Basic School }\end{array}$} & 1 & $\begin{array}{l}\text { Yes ... maybe not with that term. But for example, addressing issues related to the care for nature, } \\
\text { pollution, all of this is related to topics taught in the first cycle. }\end{array}$ \\
\hline & 2 & $\begin{array}{l}\text { Yes, because it's for the good of our planet (...) the sooner children become aware of the needs of our } \\
\text { planet and of our life together, the better will the world become... }\end{array}$ \\
\hline \multirow[t]{2}{*}{$\begin{array}{l}2^{\text {nd }} \text { Grade of } \\
\text { Basic School }\end{array}$} & 3 & $\begin{array}{l}\text { Yes. In a more or less direct way, I think that it allows students to realize that they must respect what } \\
\text { they have in terms of natural resources. They should also want others, in the future, to have those } \\
\text { resources at their disposal. }\end{array}$ \\
\hline & 4 & Yes, in the sense that there is a greater awareness regarding sustainable development. \\
\hline \multirow[t]{2}{*}{$\begin{array}{l}3^{\text {rd }} \text { Grade of } \\
\text { Basic School }\end{array}$} & 5 & $\begin{array}{l}\text { Yes, because the younger students are, the easier it is to discuss the ideas they have (...) they ask many } \\
\text { questions. The older ones do not say anything, even when they disagree. }\end{array}$ \\
\hline & 6 & $\begin{array}{l}\text { Well, maybe the 3rd cycle is not the best time to do it. This is rather a complicated age, at which teenagers } \\
\text { try to affirm themselves and we know this means denying everything that is stated, all that is imposed or } \\
\text { told. Maybe this age is not the best time for introducing awareness and accountability. Nonetheless, if } \\
\text { growing stages are duly taken into account, I believe that it should be taught at any age. }\end{array}$ \\
\hline \multirow[t]{2}{*}{$\begin{array}{l}\text { Secondary } \\
\text { School }\end{array}$} & 7 & $\begin{array}{l}\text { Yes, of course, because in secondary education, we are already talking about people who are in a } \\
\text { Science-Humanities science course, that is, students who will most likely have to deal with biological } \\
\text { and geological resources in their professional life. }\end{array}$ \\
\hline & 8 & $\begin{array}{l}\text { Yes. Any time is a good time to learn, both in primary and in secondary school. I believe we should } \\
\text { start at the basic schooling years. But also in secondary school, when students are more capable of } \\
\text { having an opinion, perhaps, gathering information or even developing more responsible attitudes } \\
\text { with regard to this matter. }\end{array}$ \\
\hline
\end{tabular}

Table 13. According to the curricula goals for teaching natural sciences/geology, in which topics would you include notions of Geotethics?

\begin{tabular}{|c|c|c|}
\hline Teachers & Code & Examples \\
\hline \multirow[t]{2}{*}{$\begin{array}{l}1^{\text {st }} \text { Grade of } \\
\text { Basic School }\end{array}$} & 1 & $\begin{array}{l}\text { The themes: "Discovering the natural environment" and "Discovering the interrelations between nature } \\
\text { and society." }\end{array}$ \\
\hline & 2 & "Discovering the natural environment" and "Discovering the interrelations between nature and society." \\
\hline \multirow[t]{2}{*}{$\begin{array}{l}2^{\text {nd }} \text { Grade of } \\
\text { Basic School }\end{array}$} & 3 & $\begin{array}{l}\text { I think immediately in the first topic, "The water, air, rocks and soil - earth materials", in which students } \\
\text { address a little bit all these sustainable development issues (...) There is still no indication to teach it, } \\
\text { because teachers worry more with the quick presentation of the contents than with making students think } \\
\text { about what is important, and what they can do to improve both the present and the future. }\end{array}$ \\
\hline & 4 & $\begin{array}{l}\text {... maybe the topic "The water, air, rocks and soil - earth materials". Also the topic "Vital Processes } \\
\text { Common to Living Beings". A transversal path can be found here ... for such an approach. }\end{array}$ \\
\hline \multirow[t]{2}{*}{$\begin{array}{l}3^{\text {rd }} \text { Grade of } \\
\text { Basic School }\end{array}$} & 5 & $\begin{array}{l}\text { The topics "Geological science and sustainability of life on Earth," "Sustainable Management of } \\
\text { Resources" and "Individual and community health". In the latter, Geoethics stands as one factor that } \\
\text { may or may not condition the quality of life of an individual. }\end{array}$ \\
\hline & 6 & $\begin{array}{l}\text { Clearly the topic "Sustainable Management of Resources". This does not mean that it does not branch } \\
\text { out to other areas and issues. Also, albeit not so clearly, the topic on "Individual and community } \\
\text { health", which also addresses some topics related to the ecosystem and the atmosphere and } \\
\text { hydrosphere ... We cannot forget that the ecosystem is the result of several subsystems, all interconnected, } \\
\text { one of which is geology, the Earth; but the Earth is not a subsystem isolated from the others (...) this is a } \\
\text { relevant topic in today's society as well as in the education of young people whom we want to be } \\
\text { increasingly enlightened so as to act in respect for sustainability. }\end{array}$ \\
\hline \multirow[t]{2}{*}{$\begin{array}{l}\text { Secondary } \\
\text { School }\end{array}$} & 7 & $\begin{array}{l}\text { Sustainable development could be included in the topic "Earth, a very special planet." Also when } \\
\text { addressing the issue of management of water supplies. In the final year it is also discussed the } \\
\text { preservation and improvement of the environment. }\end{array}$ \\
\hline & 8 & $\begin{array}{l}\text { We address natural resources; we talk about sustainable development and the sustainable use of } \\
\text { resources. I believe it could be introduced in this topic. }\end{array}$ \\
\hline
\end{tabular}


to consistently recognize ethical geosciences dilemmas and develop strategies and skills that would enable them to address sustainability and development issues responsibly, i.e., with respect for the environmental sustainability of the planet and the social and economic well being of both present and future generations. Without this ethical dimension their performance as future geologists will surely be incomplete. Also, without a previous knowledgeable awareness of the multiple issues related to Geoethics (IAPG - PNS) it will be impossible to pursue its educational significance and benefit from its multiplier educational effect. Effective teaching tools directed at the development of awareness for Geoethics are needed, enabling young people to become conscious and active citizens.

\section{Acknowledgements}

This research was carried out within the scope of the Research Project FCT-Pest-OE/CTE/UI0039/2014, funded by FCT - Fundação para a Ciência e a Tecnologia.

\section{References}

Almeida, A., and Vasconcelos, C., 2014, Geoethics Masters' Students knowledge and perception of its importance: Research in Science

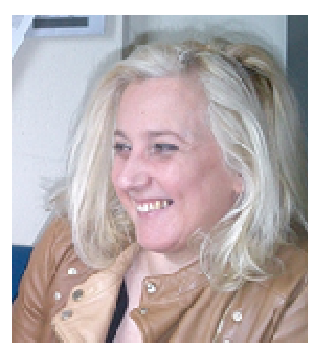

Clara Vasconcelos is an Assistant Professor with Aggregation in Science Education at the Faculty of Sciences of the University of Porto - Portugal. She took a PhD in Education in 2001 after a Master in Management Education and graduation in Geology with a specialization in Geology Teaching. She participates in different research projects and has published several articles and books in the area of science education and geoscience teaching. She is the Portuguese National Coordinator of the International Association for Promoting Geoethics.

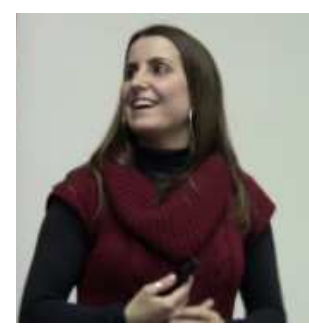

Joana Torres is currently a FCT PhD granted student at the Science Teaching and Dissemination Programme, Faculty of Sciences of the University of Porto. She has participated in different research projects both as a collaborator and as grant holder. She is a Biology graduate and has a Master Degree in Biology and Geology teaching in the Faculty of Sciences of Porto University.
Education. DOI: 10.1007/s11165-014-9449-3.o

World Commission on Environment and Development, 1987, Our common future: Report of the World Commission on Environment and Development. Oxford: Oxford University.

IAPG (International Association for Promoting Geoethics) website (http://www.iapg.geoethics.org/)

IAPG - PNS (International Association for Promoting Geoethics Portugal National Section) web site (http://web.fc.up.pt/iapg-pns)

Matteucci, R., Gosso, G., Peppoloni, S., Piacente, S, and Wasowski, J., 2014, The "Geoethical Promise": A Proposal: Episodes, v. 37, no. 3, pp. 190-191.

UNSD (United Nations Statistics Division)

web site (http://unstats.un.org/unsd/environment/indicators.htm) Vasconcelos, C., 2012, Teaching Environmental Education through PBL: Evaluation of a Teaching Intervention Program: Research in Science Education, v. 42, no. 2, pp. 219-232.

Vasconcelos, C., and Almeida, A., 2014, Sustentabilidade e Questões de (Geo)ética: Revista de Ciência Elementar, v. 2, no. 3, pp. 4144.

Peppoloni , S., and Di Capua, G., 2015, The meaning of Geoethics, in Wyss M., and Peppoloni, S., eds, Geoethics: Ethical Challenges and case studies in Earth Sciences:The Netherlands, Elsevier, pp. 3-14.

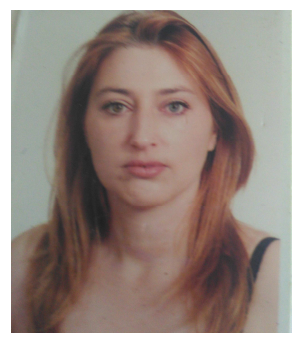

Luisa Vasconcelos is a PhD in Arts - Politics and International Relations, University of Aberdeen. She holds an MLitt in Strategic Studies from the same university and she has a degree in Economics from the Faculty of Economics of the University of Porto. She has been a teacher at the University Fernando Pessoa since 1994 and holds research interests related to macroeconomics, growth and development. She was advisor to the Secretary of State for Trade, Services and Consumer Protection, at the Ministry of Economy, in the XVII and XVIII Constitutional Governments, and served as deputy at the National Parliament in VIII Legislature.

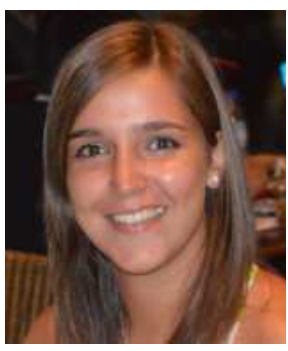

Sara Moutinhois currently a PhD student in Science Teaching and Dissemination Programme at the Faculty of Sciences of the University of Porto. She graduated in Biology and has complementary training in Geology. She has a Master Degree in Biology and Geology Teaching in the Faculty of Sciences of the University of Porto. 